\title{
Characteristics and Problems of Free Trade Agreements Involving East Asian Countries
}

\author{
Jung Taik Hyun* and Jin Young Hong**
}

\begin{abstract}
The economic success of East Asia was due to an export-led growth strategy, which was heavily dependent on the global trading system underpinned by the General Agreement on Tariffs and Trade (GATT) and the World Trade Organization (WTO). In recent years, however, East Asian countries have shifted their trade policy focus to regional agreements and made Free Trade Agreements (FTAs) among themselves and with other regions. Government organization has been restructured to increase FTA activities. Generally, the current literature predicts that FTA activities of East Asia would help to increase the welfare of the region. In this paper, we offer a critical assessment of East Asia FTAs. We note that East Asia FTAs provide incomplete coverage of sectors and are likely to lead to an inefficient resource allocation. FTA movements are not matched with actual trade flows. The benefits of East Asia FTAs are fairly limited and potential benefits, if any, would not likely be materialized in the near future. Our overall assessment is that the recent policy shift in East Asian countries from multilateral trade orientation or unilateral action to regionalism or a parallel multilateral and regional trade approach will not produce much gain. The governments should increase their efforts at economic reform and reduce barriers to trade and investment, rather than to allocate more resource and manpower to FTA activities.
\end{abstract}

Keywords: Free Trade Agreement, Trade Policy, WTO, APEC, East Asia

\section{INTRODUCTION}

Regionalism has not been prevalent in East Asia. Economic growth in Japan, Korea, China and other countries in East Asia has been heavily dependent on trade, but this trade has been based on the multilateral trading system underpinned by the General Agreement on Tariffs and Trade (GATT) and its successor, the World Trade Organization (WTO). While Europe began its economic integration with the European Economic Community in the 1950s, and the U.S. started its negotiation on a free trade agreement in North America in the mid-1980s, East Asia showed little interest in regional trade agreements.

- Professor, * Ph.D. Candidate, School of International Trade and Regional Studies, Inha University, 253 Yonghyun-dong, Nam-Ku Incheon 402-751, Korea, E-mail: jthyun@inha.ac.kr. The authors would like to thank Professors Peter J. Rimmer (The Australian National University), Edward Tower (Duke University), and Michele D. West (Inha University) for valuable comments on the draft. 
From the mid-1990s, the situation changed. The ASEAN countries signed the first free trade agreement in Asia, the Asia Free Trade Area (AFTA) in 1992. Japan signed a Japan-Singapore Economic Partnership Agreement in 2002 and a FTA with Mexico in 2004. The Japanese revised its trade policy strategy from a multilateral focus to the parallel approach of multilateral and regional trade agreements. The economic and foreign ministries of the government have been restructured for FTA activities. Korea signed a FTA with Chile in 2003, and concluded negotiations with Singapore in 2004. The Korean government set up a new bureau with four divisions to work exclusively for FTAs in 2004. ' China and the ASEAN group signed a framework agreement in 2002 to establish a free trade area.

Efforts by Asian countries to negotiate FTAs have received relatively favorable evaluations from current studies, which predict welfare gains (Cheong and Lee, 2000; Cheong, 2001; and Kawasaki, 2003). A bright vision of East Asian economic integration has also been presented. Lee (2003) notes: "it is quite likely that we will see the emergence of an East Asia FTA." Baldwin (2004) also predicts that a domino effect will soon be triggered in East Asia and all major nations can be pulled eventually into a single agreement. With increasing activities for FTAs and the increase in the number of predictions, the government policymakers may fall into self-complacency believing that a policy shift to FTAs is the right choice. We try to explain that such confidence, if yielded to by the government, would be unjustified and dangerous in contemplating a proper policy prescription.

This study attempts to make a critical assessment of ongoing movements regarding FTAs in East Asia. It analyzes legal structures and characteristics of current Asia FTAs, comparing them with those of the European Union (EU) and the North American Free Trade Agreement (NAFTA). We find that East Asia FTAs provide incomplete coverage of sectors and are likely to lead to inefficient resource allocation. FTA movements are not matched with actual trade flows and therefore, the benefits of East Asia FTAs will be fairly limited. We explain that the results of current studies using the simulation model need to be carefully interpreted. We also examine whether East Asia FTAs can lead to a broader regional agreement or an East Asian Free Trade Area as suggested by the 'domino' argument. Our overall assessment is that the recent policy change of East Asian countries from multilateral trade orientation to regionalism or a parallel multilateral and regional trade arrangement will not produce much gain. We try to draw some policy implication from the study, reflecting on existing commitments of East Asian countries and the need for economic reform.

Section II illustrates trends of regionalism in East Asia. FTA activities of the three Northeast Asian countries - Korea, China and Japan - and ASEAN countries are described. In Section III, we examine East Asia FTAs from various aspects. Firstly, the

\footnotetext{
' Ministry of Foreign Affairs and Trade of Korea, 2004.
} 
legal nature and coverage of sectors and its implication for efficiency is examined. Second, we compare FTA movements with actual trade flows. Third, we try to evaluate the potential benefits to be derived from East Asia FTAs and reconcile the predictions of current studies. Fourth, we examine the possibilities of expansion or the establishment of a broad East Asia FTA. Section IV provides some thoughts on policy options of East Asian countries. The final section summarizes the main findings and suggestions.

\section{TRENDS OF FREE TRADE AGREEMENTS IN EAST ASIA}

It is generally recognized that the FTA of ASEAN countries signed in 1992 was the starting point of East Asian regionalism. However, it is worth mentioning Asia Pacific Economic Cooperation (APEC) forum, which was launched before this event. APEC is not a regional trade agreement, but a unique form of economic cooperation for promoting trade and investment liberalization, business facilitation and economic and technical cooperation among Asia-Pacific countries. ${ }^{2}$ The economies of APEC share 60.4 per cent of the GDP and 46.9 per cent of the trade in the world. Notably, both the U.S., the biggest economy in the world, and Japan, the second largest, are members of APEC. The three NAFTA countries and most East Asian countries are in APEC.

APEC is not a FTA in legal term, but it has a plan to achieve free trade in the region. At the APEC Summit Meeting in Bogor, Indonesia in 1994, the leaders adopted the 'Bogor Goals', where they announced their commitment to complete trade liberalization by 2010 in developed countries and by 2020 in developing countries. In the following years, agendas and action plans to achieve free trade in the region have been set out. If the 'Bogor Goals' are realized and the commitments of the member countries are fully implemented, APEC economies can enjoy a substantial welfare improvement through free trade opportunities in the region, without creating formal trade agreements. APEC adopted an 'open regionalism' as the underlying paradigm, with the intention of sharing the benefits of free trade with non-members and thus trying to comply with the most favored nation (MFN) principle of the WTO. The modality of the APEC trade liberalization is a concerted unilateralism: member economies individually or collectively announce liberalization plans and a peer-review process monitors the progress of the plans. The APEC also implemented a number of business facilitation programs, including an APEC Business Travel Card, and economic cooperation, including digital networking. The work of APEC in trade liberalization did not achieve much success. However, it should not be viewed as a failure of 'open regionalism', but rather the result of the diversification of the APEC agenda, including anti-terrorism and weapons of mass destruction. Choi (2004) notes that the APEC process motivated Indonesia's trade liberalization in the 1990 s.

2 The original 12 members that participated in the first APEC meeting in Canberra in 1989 were Japan, Korea, six ASEAN countries, the U.S., Canada, Australia and New Zealand. Later its membership expanded to 21 economies including China, Russia and Mexico. 
The Bangkok Agreement, signed in 1975, is worth noting because it includes East Asian countries as members. It is not a FTA but a formal regional trade agreement reported to GATT/WTO. Korea, Bangladesh, India, Laos, Sri Lanka, the Philippines and Thailand agreed to a mutual tariff reduction. Five of the seven countries, excluding the Philippines and Thailand, ratified the agreement. In 2000, China became a member of this agreement. In 2002, the total number of items benefiting from tariff reduction was 1,571 for general concession and 112 for special consideration to least developed countries.

In 1992 six ASEAN countries (Brunei, Indonesia, Malaysia, the Philippines, Singapore and Thailand) concluded the first free trade agreement in East Asia. Its initial plan was to reduce tariffs to $0-5$ per cent among members. Originally, the target year for the Asia Free Trade Area (AFTA) was 2008, but it was later moved forward to 2002. Subsequently, the membership has been expanded to ten countries, including Vietnam, Myanmar, Laos and Cambodia. ASEAN agreed to eliminate tariffs among the original six members by 2010 and four new members by 2015 . In addition, the leaders of ASEAN announced that they aimed to transform AFTA into an ASEAN Economic Community by 2020. Despite the bold goals and vision of ASEAN, obstacles in the process of building an economic community are many. Resistance toward opening to sensitive products is high, and coordination among the member countries is not efficient enough to overcome the problems. Individual countries in ASEAN pursue separate FTAs, ${ }^{3}$ which may affect cooperation within the ASEAN group. Singapore has signed FTAs with New Zealand, Japan, EFTA, Australia and the U.S., and Thailand has concluded a FTA with Australia. Although the ASEAN economy and trade volume is small compared to major trading blocs and countries, ASEAN became the target of FTAs inside and outside the region. China and Japan have agreed on a framework to establish a free trade area with ASEAN. Korea also plans to discuss a FTA with ASEAN. The three Northeast Asian countries have regular annual meetings with ASEAN, which are called the ASEAN+3 meetings. India also has agreed on a framework of comprehensive economic partnership with ASEAN.

Japan began to explore regional trading agreements in the late 1990s. The initial "The reason why Japan converted their strategy from a GATT-WTO dependence to the direction of FTAs is the large cost of being outside of FTAs" (Igawa, 2004). The best example to fit the expression is Japan's FTA with Mexico. Negotiations with the Mexican government did not progress smoothly, due to politically sensitive issues of agriculture. The first FTA signed by Japan was the agreement with Singapore in 2002. Although the agreement included tariff reductions for manufacturing products and the liberalization of investment and services, it completely excluded agriculture. In 2004, Japan finally agreed on a FTA with Mexico. The agreement includes the elimination of tariffs on agricultural products, but Mexican chickens and oranges will remain subject to a tariff quota system. Japan also concluded the FTA negotiation with the Philippines in 2004. Currently, Japan

\footnotetext{
3 Some agreements have different names: e.g., Economic Partnership Agreement.
} 
is undertaking official negotiations on FTAs with Korea, Malaysia, and Thailand. Japan has restructured its government organization in order to meet the increasing workload of FTA activities. Japan is preparing to begin formal negotiations with ASEAN in April 2005 .

The Korean government decided to pursue FTAs with its trading partners at the Ministerial Committee on International Economic Policy in 1998. However, the approach was very cautious to minimize potential risks associated with FTAs. Chile was chosen as the first partner for the negotiation of FTAs, because of the small size of bilateral trade volume and the distance between locations. Although the FTA with Chile was intended for initiating FTA movements and building experience for Korea, it actually took a long time to conclude the agreement. Strong opposition from the agricultural sector delayed progress of the negotiation, and it was six years after the time of the Ministers' decision when Korea's first FTA became effective. The agreement excludes rice, apples and pears, and postpones tariff reductions on many agricultural products until after the conclusion of the ongoing Doha Development Agenda negotiations. Korea's second FTA was with Singapore, also a country with a relatively small bilateral trade volume and less sensitive products. Currently, the Korean government is undertaking formal negotiations with Japan, but the negotiation process is not smooth. According to the government's 'FTA roadmap', announced in 2003, the Korea-Japan FTA is targeted for conclusion within the short term. The next issue will be FTAs with ASEAN, Mexico and EFTA. The U.S., China and the EU are listed for the long-term. The Korean government is also considering a Northeast Asian FTA embracing Korea, Japan and China, and an ASEAN+3 FTA. ${ }^{4}$

China joined the WTO in 2001 and is in the process of meeting its WTO obligations. Therefore, China's interest in and resources for regional trade agreements are limited. However, China also took initiative in a FTA with ASEAN and has made progress in these negotiations. At a summit meeting held in Phnom Penh in 2002, the leaders of China and ASEAN countries announced the signing of a framework agreement for a Free Trade Area. The goal is to establish a FTA within ten years and the negotiation plan was to conclude commodity negotiations by 2004 . Given the complexity of the agreement, it would require an extensive discussion to conclude this negotiation. Presently, the negotiations are still ongoing, and not much content has been revealed with regard to ASEAN-China FTA negotiations. A notable feature of the FTA framework is an 'early harvest package', which enables tariff reduction of selected items before the completion of FTAs. Chinese scholars and government have shown some interest in a FTA with Korea, particularly after the formal Korea-Japan negotiation started. China is hesitant to form a FTA with Japan. China is also competing with Japan in the race for FTAs with ASEAN. It seems that China is ahead in a FTA with ASEAN as a group, but with regard to FTAs with individual ASEAN countries, Japan is farther along.

\footnotetext{
4 For more elaboration on Korea's FTA policy, see Hyun (2003).
} 
It is also worthwhile to examine FTAs with the U.S., and the U.S. attitude toward FTAs with East Asia and Pacific countries. Although the U.S. is not an Asian country, most East Asian countries are heavily dependent on trade with the U.S. Intra-regional trading in East Asia is also indirectly linked to the U.S., since such trade has a final export destination of the U.S. market. The U.S. strongly supported APEC and its trade liberalization plans, but was somewhat hesitant in forming a trading bloc with Asia. With increasing FTA trends around the world, the attitude seems to be changing. The U.S. has signed a FTA with Singapore, but no formal negotiation has been started yet with other countries in Asia. Among some scholars on both sides of the Pacific Ocean, FTA options between the U.S. and Asia are being explored, albeit not with much enthusiasm.

Figure 1 illustrates FTAs of East Asian countries and their partners. ${ }^{5}$ We try to highlight the contrast between vertical and horizontal arrangements (in a geographical sense). The major players in terms of trade volume are located along the horizontal axisChina, Korea and Japan in East Asia and the U.S. across the Pacific. Trade volume between these countries is quite substantial. Interestingly, no serious attempt has been made to form FTAs between these countries except the case of the Korea-Japan FTA, which also is not progressing well at the moment. FTAs between Northeast and Southeast Asian countries, i.e. vertical arrangements, are many. China has agreed with ASEAN, and Japan and Korea plan to negotiate with ASEAN as well. For separate agreements with members of ASEAN, Japan concluded agreements with Singapore and the Philippines, and Korea with Singapore. It seems that the three Northeast Asian countries are competing for FTAs with ASEAN. A FTA embracing ASEAN + 3 has been suggested on many occasions, ${ }^{6}$ but the strategy of each Northeast Asian country seems to first proceed with ASEAN + 1. There has been little sign of movement toward an agreement among the 'plus three' Northeast Asian countries. The market size and effect of a FTA would be much greater in such a horizontal integration, but, due to political and historical sensitivity, East Asian countries favor vertical options that would bring smaller benefits. East Asia FTAs with other regions are also shown in Figure 1, although not all of them are drawn for the sake of simplicity: examples of FTAs with other regions are Korea-Chile, Japan-Mexico, Thailand-Australia, Singapore with the U.S., and Australia and New Zealand. Among the East Asian countries, Singapore has concluded more FTA agreements than any other countries.

The list of East Asian FTAs is given in Annex 1.

6 The East Asia Vision Group recommended the formation of an East Asian Free Trade Area at the ASEAN+3 Summit Meeting in Brunei in 2001, and the leaders supported the idea. 
Figure 1. FTAs of East Asian Countries and their Partners

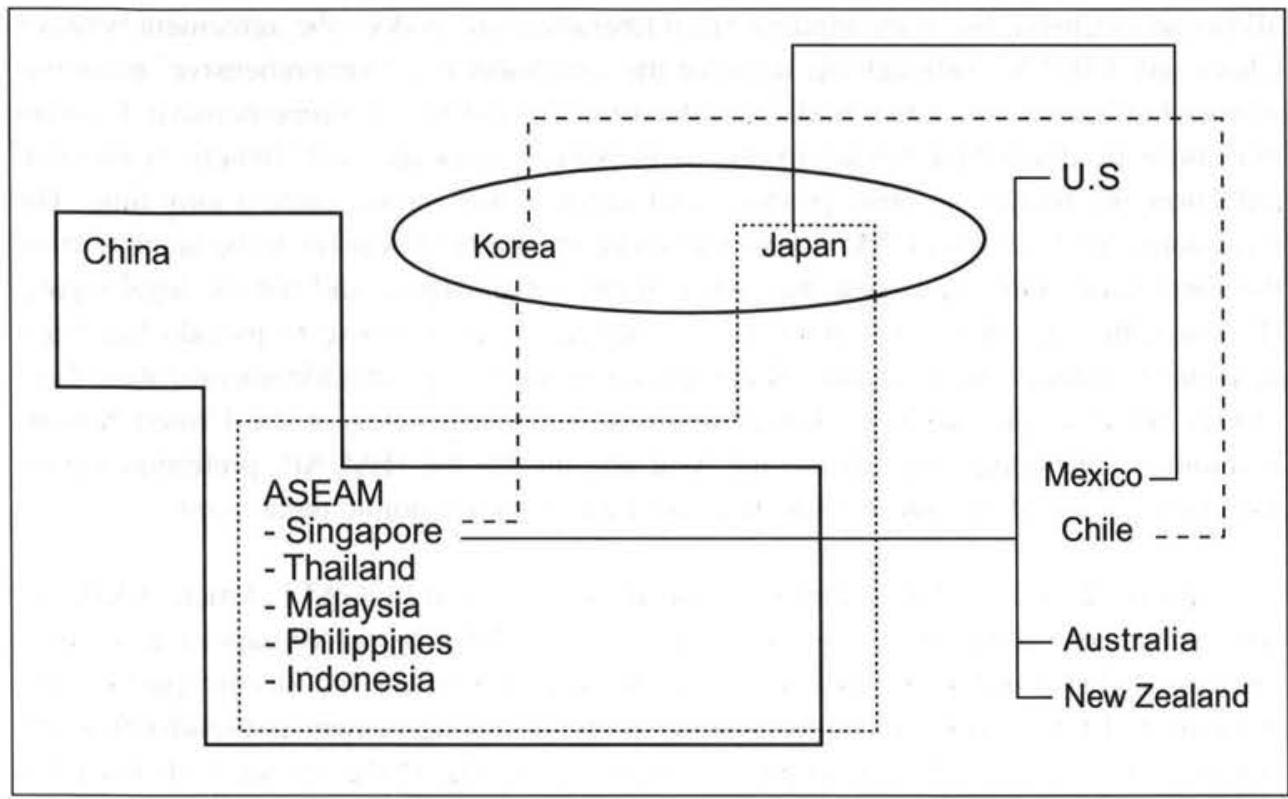

\section{ASSESSMENT OF EAST ASIA FTAS ${ }^{7}$}

\section{The scope of liberalization is incomprehensive and it is likely to increase inefficiency}

A free trade agreement is an exception to the most favored nation (MFN) principle of the WTO system. A FTA brings both a trade creation and trade diversion effect. In order for a FTA to lead to trade creation rather than diversion, the WTO set conditions for the formation of a FTA. GATT Article XXIV stipulates that in a free trade area, duties and other restrictions are eliminated on 'substantially all the trade' between members. If certain sectors are picked for trade liberalization and others are allowed to keep trade barriers, it will cause distortion in resource allocation. In many East Asia FTAs, this condition of substantial coverage is not required or appropriately reflected.

Firstly, FTAs between developing countries are not bound by the substantial coverage condition. In legal terms, such FTAs are not a 'free' trade agreements based on GATT Article XXIV. It is a preferential trade agreement allowed for developing countries by the GATT 'enabling clause'. The member countries can choose the sectors and the extent of liberalization. The Bangkok Agreement of Korea, China and other countries is

There is a risk for generalization of many different FTAs in East Asia. The characteristics and problems of East Asian FTAs in this section are drawn from comparison with EU and NAFTA. 
based on the 'enabling clause', which allows preferential tariff reduction for selected products. The FTA of ten ASEAN countries - AFTA - is also based on the clause and allows an extensive list of exemptions from liberalization, as does the agreement between China and ASEAN. Although the name of the agreement is a 'comprehensive' economic partnership agreement, actual trade liberalization will not be so comprehensive. It seems that those products that belong to an 'early harvest package' will benefit from tariff reduction, but barriers to other products and services will remain quite a long time. The legal nature of East Asia FTAs ${ }^{8}$ limits the scope of potential benefits to be accrued from the agreements. One may argue that what matters is substance and not the legal nature. However, the fact that developing Asian countries have recourse to pseudo-free trade agreements reduces the need and willingness for broader steps of trade liberalization. Low (2004), for example, suggests that a Bangkok Agreement style of the United Nations Economic and Social Commission for Asia and the Pacific (ESCAP) preferential trade agreement is one of the possible scenarios for East Asian economic integration.

Second, East Asia FTAs that are supposed to be bound by GATT Article XXIV are also partial and sometimes very much fragmented. The Japan-Singapore agreement illustrates this point well. The name of the agreement, an 'economic partnership agreement (EPA)', seems to imply that the scope of the agreement is broader than the elimination of barriers of trade in goods, and in fact, reducing the service trade barrier is addressed to some extent. However, the agreement completely excludes the agricultural sector. The Japanese government calculates that the product coverage of the agreement is 93 per cent based on the current trade volume and thus tries to claim that it meets the 'substantially all trade' condition. Based on product lines, the agreement covers only 76 per cent. According to Snape (1996), excluding all unprocessed agricultural products is not a reasonable interpretation of the term 'substantially all trade'. The Japan-Mexico FTA included agriculture, but with many reservations, including keeping a tariff quota system for oranges and chicken. Japan intends to minimize the application of the free trade principle in agricultural products in current FTA negotiations with Thailand, Malaysia and other ASEAN countries. The Korea-Chile FTA excludes rice, apples and pears, and postpones the tariff reduction of many agricultural products until the conclusion of multilateral talks in the WTO. According to Park (2004) and Nam (2004), Korea's FTA strategy and selection criterion of FTA partners are a minimization of negative impact, especially on agriculture.

A study of ADB (2002) notes that a trade agreement is beneficial if it develops so that the comparative advantage of one member to other members of the agreement is similar to that with the rest of the world. East Asia FTAs, which provide selective liberalization and allow exemption for sensitive sectors, will not develop comparative advantages. The sensitive sectors of each country are different: the Chinese are concerned with the disadvantage of industrial products as compared to Japan and Korea, and the

\footnotetext{
8 Preferential trade agreements according to strict definition.
} 
latter are concerned with agricultural products. As the number of FTAs increases, the list of excluded sectors will be expanded and the risk of inefficiency will increase. It is fair to note that few FTAs in the world fully meet the standard requirements of the GATT. However, compared to the EU and NAFTA, Asian FTAs have a larger deviation from the GATT provision. In NAFTA negotiations, the leaders in the U.S., Canada and Mexico demonstrated strong leadership in concluding an agreement of broad coverage and in not trying to escape the problems in sensitive sectors.

Regional trade agreements of East Asian countries are free trade agreements, and not a customs union. Compared with the latter, a FTA requires the strict enforcement of 'rules of origin'. East Asia FTAs are fragmented and overlapped, as can be found in FTAs of ASEAN and those of its member countries. Many ongoing negotiations of FTAs in East Asia have different time spans for completing the elimination of barriers: in some cases, tariffs are removed immediately from the effective date, but in other cases liberalization is implemented through as long as sixteen years, depending upon countries and products. Due to the complicated and overlapping features of FTAs, East Asian countries are likely to be met with problems of what Bhagwati, Greenway and Panagaria (1998) call a 'spaghetti bowl effec'. At a higher level of economic integration such as the EU, the inefficiency and risk of the spaghetti bowl effect is much smaller than that associated with FTAs in Asia.

\section{Mismatch Between East Asian Free Trade Agreements and Actual Trade Flows}

It is natural that countries with a large trade volume between each other sign FTAs. For example, intra-EU trade is close to 60 per cent of total EU trade and intra-NAFTA trade is 44 per cent. According to Summers (1991), a FTA with 'natural trading partners,' that is, where they already trade a great deal with each other, would contribute to trade creation rather than trade diversion. In East Asia, however, FTA movements do not reflect actual trade flows. Table 1 shows the trade flows between major trading countries in East Asia. The U.S. is included in the table, because all the countries in the region depend heavily on trade with the U.S. For China, Japan is the biggest trading partner with a 15.7 per cent share among China's total trade; the U.S. (14.9 per cent) is second; and Korea (6.7 per cent) third. But China currently is seeking a FTA with ASEAN, which has only a 2.1 per cent share, for reasons other than purely economic ones. Japan has a large trade volume with the U.S. (20.7 per cent) and China (16.6 per cent), but the country first signed FTAs with Singapore and Mexico, and is now negotiating with Korea (6.2 per cent). Korea also has not concluded or begun formal negotiations with China and the U.S., its largest and second largest trading partners. 
Table 1. East Asian Trade by Countries

(US\$ Million, \%)

\begin{tabular}{l|c|c|c|c|c|c}
\hline & China & Japan & Korea & ASEAN & U.S & World \\
\hline \hline China & - & 133,658 & 63,266 & 18,130 & 126,393 & 851,569 \\
& & $(15.7)$ & $(7.4)$ & $(2.1)$ & $(14.9)$ & $(100)$ \\
Japan & 142,695 & - & 52,754 & 61,254 & 177,276 & 856,936 \\
& $(16.6)$ & & $(6.2)$ & $(7.1)$ & $(20.7)$ & $(100)$ \\
Korea & 57,017 & 53,589 & - & 38,711 & 59,033 & 372,644 \\
& $(15.3)$ & $(14.3)$ & & $(10.3)$ & $(15.8)$ & $(100)$ \\
ASEAN* & 39,276 & 119,968 & 74,917 & - & 130,584 & 897,712 \\
& $(4.4)$ & $(13.4)$ & $(8.3)$ & & $(14.5)$ & $(100)$ \\
U.S & 180,797 & 173,297 & 62,445 & 126,878 & - & $2,028,861$ \\
& $(8.9)$ & $(8.5)$ & $(3.1)$ & $(6.2)$ & & $(100)$ \\
\hline
\end{tabular}

Note: *Sum of ASEAN's individual member country's data

Source: IMF (2003), KITA (2003)

In order to evaluate the relative importance of trading partners, we examine the trade intensity index of East Asian Countries (Table 2). The trade intensity index $\left(I_{i j}\right)$ is defined as:

$$
I_{i j}=\frac{X_{i j} / X_{i}}{M_{i} / M_{w}}
$$

where $X_{i j}$ is country $i$ 's exports going to country $j, X_{i}$ country $i$ 's total exports, $M_{j}$ country $j$ 's total imports, and $M_{w}$ world imports

If the bilateral trade intensity index takes a value above or below unity the countries have greater or smaller bilateral trade than would be expected, based on the partner's share in the world. In the first row of Table 2, Japan shows the highest index (2.74), implying that the Japanese market is most important for China. The Korean market (2.0) is also important. The trade intensity indices reveal that China's trade relations with ASEAN countries (0.90-2.34), the selected FTA partner, are not as strong as those with Northeast Asian countries. China is the most important trading partner for Korea, with the highest index (3.41). It is much higher than that for Japan (1.8), the partner of ongoing FTA negotiations. Trade intensity indices representing intra-ASEAN trade, in general, are big. In fact, the largest number in the Table is that for Malaysia-Singapore (9.57). In contrast, the indices for Singapore with Japan and Korea are below unity (0.42 and 0.56 ). From the Table we can see that the AFTA, the ASEAN trade pact, is based on trade intensity, but vertical FTAs such as Japan-Singapore, Korea-Singapore and ChinaASEAN are not. FTAs between Northeast Asian countries would match actual trade flows. Among the Northeast Asian countries, the China-Japan and Korea-China pairings seems to be more trade intensive than the Korea-Japan pair where a FTA is being negotiated. 
Table 2. Trade Intensity Index

\begin{tabular}{l|c|c|c|c|c|c|c|c|c}
\hline & China & Japan & Korea & US & Singapore & Thailand & Malaysia & Indonesia & Philippines \\
\hline \hline China & - & 2.74 & 2.0 & 1.30 & 1.23 & 0.90 & 1.32 & 2.44 & 0.90 \\
Japan & 2.3 & - & 3.21 & 1.47 & 1.91 & 3.49 & 2.25 & 3.64 & 3.97 \\
Korea & 3.41 & 1.8 & - & 1.09 & 1.45 & 1.34 & 1.87 & 4.17 & 3.19 \\
U.S & 0.74 & 1.46 & 1.45 & - & 1.39 & 0.83 & 1.42 & 0.83 & 2.29 \\
Singapore & 0.57 & 0.42 & 0.56 & 0.26 & - & 1.33 & 4.52 & n.a & 1.42 \\
Thailand & 1.02 & 2.88 & 0.86 & 1.01 & 4.45 & - & 4.55 & 6.77 & 4.19 \\
Malaysia & 1.22 & 2.17 & 1.26 & 1.17 & 9.57 & 4.51 & - & 4.85 & 2.84 \\
Indonesia & 0.37 & 4.53 & 3.09 & 0.72 & 5.38 & 2.34 & 3.65 & - & 3.22 \\
Philippines & 1.61 & 3.24 & 1.58 & 1.20 & 4.08 & 3.50 & 6.40 & 1.95 & - \\
\hline
\end{tabular}

Source: KITA (2003)

It is desirable for trade agreements to be made between countries with complementary trade structures and not competitive ones. Among East Asian countries, the Korea-Japan trade relation is thought to be competitive and in contrast, the JapanChina trade is complementary. In Table 3, we compare the top ten export products of Korea, Japan, China and the U.S. The four-digit HS code numbers are shown in the table for simplicity, and the name of the products are listed in Annex 2. We note that the top (8703: motor cars and other motor vehicles) and the second (8542: electronic integrated circuits and micro assemblies) export products of Korea and Japan are exactly the same products. Comparing Japan with China, such similarity is hard to find, although some common product numbers are listed. The Korea-US relationship also seems to be more complementary than the Korea-Japan relationship. Among the four countries in the list, FTAs are currently negotiated only between Korea and Japan, which have highly competitive trade structures.

Table 3. Top Ten Export Products of Korea, China, Japan and the U.S.*

\begin{tabular}{c|c|c|c|c}
\hline Rank & Korea & Japan & China & U.S \\
\hline \hline 1 & 8703 & 8703 & 8471 & 8542 \\
2 & 8542 & 8542 & 8473 & 8708 \\
3 & 8525 & 0 & 8525 & 8802 \\
4 & 8901 & 8708 & 8529 & 8703 \\
5 & 8473 & 8473 & 8542 & 8471 \\
6 & 8471 & 8525 & 6204 & 8411 \\
7 & 2710 & 8479 & 8521 & 8473 \\
8 & 8529 & 8901 & 8517 & 9880 \\
9 & 8708 & 8529 & 8504 & 8803 \\
10 & 8528 & 8541 & 9013 & 3004 \\
\hline
\end{tabular}

Note: *Four-digit HS code number of export products

Source: KITA (2003) 


\section{Limited Benefits of East Asian Free Trade Agreements}

Many studies estimate the effects of FTAs in the East Asian region. With a few exceptions, the results of these studies show that FTAs would bring positive effects to the member countries. Cheong (2001) estimates that a Korea-Japan FTA would increase Korea's GDP by $0.82-1.90$ percentage points. Igawa (2004) estimates that a JapanASEAN FTA would increase the GDP of Japan by US $\$ 10-20$ billion and of ASEAN by US $\$ 40-80$ billion. A Singapore-Japan EPA would increase the GDP of Singapore by 5.76 per cent according to Urata (2003). The study gives comfort and satisfaction to those scholars in favor of FTAs and particularly to the government policymakers participating in FTA activities: they can say, "See, we are in the winning game." As formal negotiations of FTAs and studies predicting their gains accumulate, the potential series of FTAs looks like a winning spree. The satisfaction garnered from this may devolve into a self-conviction that we are, indeed, on the right track. However, before reaching such a conclusion, we need to understand the nature of these studies and to carefully interpret the estimated results.

Most studies of FTA related estimations are based on a 'simulation' of a computable general equilibrium (CGE) model. The estimation result of the model is a numerical expression of what an economic theory tells about reducing trade barriers, in a very sophisticated form. The gains come from trade liberalization, and the study results should not be interpreted for supporting the FTA, per se. When trade barriers are removed, domestic buyers of final and intermediate goods shift toward imports and competing industry contracts production, while resources are shifted toward more competitive industry. Although some sectors lose profitability, the economy as a whole will benefit from trade. Reducing trade barriers increases the efficiency of allocation; this is what classical trade theory predicts. The new trade theory explains a further source of gains: trade liberalization will increase competition in an imperfectly competitive market and thus reduce cost. Due to an increasing return to scale, the expansion of the market will reduce costs and bring additional benefit. According to a dynamic analysis, trade expansion will increase capital stock, and thus bring about the effects of economic growth. There are also adverse effects from trade liberalization. The reduction in trade barriers and changing trade patterns caused by liberalization may adversely effect the terms-of-trade of a country. However, the possibility that this terms-of-trade effect will offset the total gains of trade from allocation efficiency, enhanced competition, increased returns to scale and capital accumulation are very small. Trade liberalization, whether it is unilateral, bilateral, regional or multilateral, all have the effects described above according to the theory. Therefore, it is not surprising that most studies of FTAs using CGE models predict positive welfare effects for the member countries.

Krueger (1999) points out that the outcome of the studies depends on the way in which the system is modeled. For example, if the model assumes a larger scale economy, simulation results will show bigger gains of a FTA. She suggests that a more objective assessment would be based on empirical examination with actual data of pre- and postFTAs. With regard to the EU and NAFTA, empirical studies have been performed, but 
East Asia has not yet accumulated any post-FTA data and empirical testing to provide conclusive evidence must be the subject of future study.

Considering the trading patterns and current trends of FTAs in East Asia, however, it is conceivable that the benefits from East Asia FTAs will be fairly limited. Table 4 illustrates FTA partners' rank and share of trade in three East Asian countries. Korea first concluded a FTA with Chile, which is its $46^{\text {th }}$ trading partner with a share of only 0.3 per cent. The second FTA is with Singapore, which ranks 11 th with a 2.4 per cent share. Japan also signed a FTA with Singapore, which is its $12^{\text {nd }}$ partner at 3.2 per cent. Mexico, the second FTA partner of Japan, ranked $24^{\text {th }}$ with a share of 0.9 per cent among total Japanese exports. Recently, the Japanese concluded a FTA with the Philippines, which ranked $17^{\text {th }}$ at a 1.9 per cent share. According to a report announced by the Cabinet office of Japan, the FTA with Singapore would increase the GDP by 0.002 per cent. ${ }^{9}$ The agreements with Mexico would increase Japanese GDP by 0.06 per cent and the agreement with the Philippines 0.01 per cent. The situation is not much different in the case of China. Currently, the country is negotiating a FTA with ASEAN countries, but most ASEAN countries have a minimal share in Chinese exports: the Philippines, $27^{\text {th }}(0.7$ per cent), Thailand, $24^{\text {th }}(0.9$ per cent $)$, Indonesia, $21^{\text {st }}(1.0$ per cent $)$, Malaysia, $19^{\text {th }}(1.4$ per cent) and Singapore, $13^{\text {rd }}(2.0$ per cent $)$. It is indeed a distinctive and peculiar facet of East Asia FTAs that major trading partners are not given higher priority for FTAs. Regional trade agreements in other parts of the world are concluded among the major trading partners: not only the EU and NAFTA, but MERCOSUR and EFTA has significant intra-bloc trade. With all the talks and efforts made for FTAs in East Asia, the effects of the agreements seem to be fairly limited.

\footnotetext{
9 Yomiuri On-line, 2004.
} 
Table 4. East Asian FTA Partners' Rank and Share of Trade (\%: share)

\begin{tabular}{|c|c|c|c|c|c|c|}
\hline Rank & \multicolumn{2}{|c|}{ Korea } & \multicolumn{2}{|c|}{ Japan } & \multicolumn{2}{|l|}{ China } \\
\hline 1 & China & (18.1) & U.S & (24.6) & U.S & (21.1) \\
\hline 2 & U.S & (17.7) & China & (12.2) & Honking & (17.4) \\
\hline 3 & Japan & (8.9) & Korea & (7.4) & Japan & (13.6) \\
\hline 4 & Honking & (7.6) & Taiwan & (6.6) & Korea & (4.6) \\
\hline 5 & Taiwan & (3.6) & Honking & (6.3) & Germany & $(4.0)$ \\
\hline 11 & Singapore & (2.4) & & & & \\
\hline 12 & & & Singapor & (3.2) & & \\
\hline 13 & & & & & Singapore & (2.0) \\
\hline 17 & & & Philippin & es (1.9) & & \\
\hline 19 & & & & & Malaysia & (1.4) \\
\hline 21 & & & & & Indonesia & (1.0) \\
\hline 24 & & & Mexico & $(0.9)$ & Thailand & (0.9) \\
\hline 27 & & & & & Philippine & $s(0.7)$ \\
\hline 46 & Chile & (0.3) & & & & \\
\hline
\end{tabular}

Source: KITA (2003)

\section{Prospect of Expanding the Regional Agreements}

Interestingly, many government officials and scholars in East Asia have proposed a bold vision of establishing an East Asia FTA, despite small progress made so far. At the ASEAN+3 meeting in Brunei in 2000, Korean President Kim Dae-jung proposed that an East Asian Free Trade Area be approached based on the East Asian Vision Group recommendations. At the Boao Forum in 2002, Chinese Premier Zhu Rongji stated that China would start economic cooperation in the sub-region first, and then expand to the whole of Asia. The dream is that the region could expand the scope of FTAs with the accumulation of FTA experience and would finally create an East Asian trading bloc. Lee (2003) considers three possible scenarios that lead to the establishment of an 'East Asian Free Trade Area'. The first path is to accelerate the regional economic integration process through the existing ASEAN+3 framework. The second is a series of bilateral FTAs in the region leading to the formation of an East Asia FTA. The third is the expansion of the path from ongoing negotiations of Korea-Japan to a China-Japan-Korea FTA and finally to an East Asia FTA by combining the ASEAN countries.

Seemingly, countries in East Asia have different preferences. The ASEAN countries that have already formed the AFTA of ten countries do not seem to feel urgency in 
establishing a new expanded bloc. If they have to choose, they would prefer the first scenario, in which they can maintain the role currently possessed in ASEAN+3 meetings. Singapore, which has actively pursued bilateral FTAs with many countries, would prefer the second scenario. The Korean government has not explicitly expressed any policy direction or strategy regarding the East Asian FTA formation process. Lee (2003) chooses the third scenario as the most plausible one and Cheong (2002) also agrees. According to the 'roadmap' of the Korean government, the FTA with Japan is a short-term goal and a FTA with China or a regional FTA is a medium to long-term goal; thus the government implicitly supports the third scenario.

Chinese scholars have considered two different options for East Asian economic integration: a horizontal integration and a vertical one (Sheng, 2003). Some have preferred a horizontal China-Korea-Japan FTA, the nature of which is complementary and has a broad scope of trade expansion. However, the Chinese government has chosen the other approach, by pursuing a vertical China-ASEAN FTA. China does not have enough confidence to form a partnership with industrialized Japan and Korea. China also considers that the reluctance of Korea and Japan to open agricultural markets would reduce the chance of an early conclusion to a horizontal FTA of the three countries. Therefore, priority was given to a China-ASEAN FTA, in the hope that this FTA would ultimately lead to an East Asia FTA. On the other hand, the Japanese strategy is to conclude the Korea-Japan FTA early, and, at the same time, to expedite FTAs with individual ASEAN countries and the ASEAN group as a whole. Japan does not display as much enthusiasm for a FTA with China. The Japanese believe that China's level of development and openness makes it difficult to agree to a broad trade liberalization plan. Our assessment is that the competition of Japan and China in East Asia FTAs is so strong that the possibility of Japan and China joining in a FTA is very slim. ${ }^{10}$

Baldwin (2004) asserts that a domino effect will soon be triggered in East Asia and that all major nations will eventually be pulled into a single agreement. He considers the Korea-Japan FTA as the most plausible gravitational force initiating FTA enlargements in East Asia. However, we believe that strong rivalry, particularly between Japan and China, will make it difficult for a 'domino process' to occur. The different nature of agreements and the discrepancy in interested sectors also limits the chance of creation of a free trade area in East Asia at an early stage. With regard to the Japan-Korea FTA, which Baldwin (2004) thinks important in terms of exclusion indices in East Asia, two points are worth mentioning. Firstly, the short-term goal of concluding a Korea-Japan FTA is not without challenges. Seliger (2003) examines historical and cultural obstacles that must be overcome to conclude the bilateral FTA, and Schott and Goodrich (2004) describe strong political resistance to reform in Korea and Japan. In fact, the progress of Korea-Japan

10 The first author visited government ministries of Japan and China in February 2004. The officials of both governments thought that a Japan-China or Japan-Korea-China FTA would not be possible in the near future. 
negotiation is very slow, and difficulties are ahead." Second, a Korea-Japan FTA may delay the restructuring process and have the effect of deterring a broader liberalization effort. Nam (2004) points out that the choice of a Korea-Japan FTA was motivated by pacifying the interests of their agricultural sectors, and that such a FTA has the effect of protecting inefficient agricultural production and increasing the mutual cooperation of the farmers of these two countries against opening the door to exports from China, ASEAN and other countries.

\section{TRADE POLICY IMPLICATION}

Panagaria (1999) notes: "The only region which has so far remained firmly committed to the MFN approach to liberalization is East Asia". The 'firm' commitment of East Asia to the MFN principle is now lost in the race for FTAs. Japan made it public that its trade strategy, based on the multilateral trading system, has changed to a parallel approach of multilateral and regional trade. Korea, China and Southeast Asian countries also adopted regionalism. Manpower and government resources are being shifted to FTA activities. The previous section illustrated that the policy change of East Asian countries would produce little gain and risk efficiency in resource allocation.

The policy-makers of the East Asian countries should reconcile the values of the multilateral trading system upon which their economic success has been achieved. They need to revitalize their commitment to MFN based trade liberalization and support new multilateral trade reforms in the WTO. In this regard, the study of Brown, Deardorff and Stern (2003) provides an interesting comparison between ongoing Doha Development Agenda (DDA) negotiations in the WTO and regional FTA options in East Asia. The DDA estimations are based on proposals put forward by WTO member countries and assume a 33 per cent tariff reduction, while the FTAs assume elimination of tariffs (100 per cent reduction) between member countries of the agreement. They find that the ' 33 per cent tariff reduction' of the DDA brings three to four times the gains from the complete elimination of trade barriers of a Korea-Japan FTA. The DDA options, according to the study, would bring similar benefit to that of an ASEAN+3 FTA. Concluding the DDA negotiations is not easy task. However, as we have examined in this paper, the vision of an ASEAN+3 FTA is much harder to achieve and even a Korea-Japan FTA will be met with strong obstacles.

The recent increase of the East Asia FTA movement is motivated by the regionalism in other parts of the world, which Schott and Goodrich (2004) calls a 'me-too' regionalism. In particular, the departure of the U.S., the long-standing trading partner of East Asia, from its conventional multilateral disposition to NAFTA and further movement toward regional agreements has greatly affected the government policies of East Asian

"The Korea Times (2004) described that it would be a miracle if both governments would hammer out an accord, and that there is absolutely no way for the agreement to pass through the National Assembly. 
countries. It is beyond the scope of this paper to analyze the regionalism prevailing outside the region. Also, it would be difficult for East Asia to change the situation or to adhere to the MFN trade principle alone. We note two points that are relevant for the trade policy of East Asian countries. First there is a growing need for refining the discipline of regional trade agreements in WTO articles (Snape, 1996, and Panagaria, 1999). The existing rules for FTAs are reviewed so that their adverse impact to MFN liberalization can be reduced. Second, the merit of the U.S. continuing its regionalism is doubted. Gordon (2003) asserts that U.S. interests are harmed by FTAs and that the U.S. should inspire the WTO and to make efforts to conclude the DDA. The East Asian countries, on their part, should strengthen efforts to revitalize the WTO, from which they greatly benefited.

The East Asia FTAs tend to increase inefficiency. The selection criteria are a minimization of adverse political impact and not the maximization of economic gains. The inefficient sectors, notably agriculture in Korea and Japan, are excluded from the FTA requirement of liberalization, and thus FTAs worked against comparative advantage. It is not unusual that trade liberalization is opposed by the public. The problem of many East Asian governments in FTA movements is that they tend to accommodate the perception of the people. The proper approach the government should take is to overcome the opposition, to prove the gains of liberalization, and to proceed with an efficiencyoriented choice that is economically justified.

The restructuring of government agencies and allocating more manpower to FTA activities are also of concern. Hyun and Hong (2004) state that the current problems of the trade policy of Korea are not associated with negotiation strategy or the negotiating body of the government, but lack of political will and efficient systems to implement trade and economic reform. In the 1980 s, Korea implemented many programs of unilateral trade liberalization. Import licensing required for a majority of the products in 1979 was abolished. The average tariff rate of manufacturing products was reduced from 20.3 per cent in 1985 to 6.2 per cent in 1992 . The open-door policy of China, which contributed to the rapid economic growth of the country, was also unilateral action initiated by Deng Xiaoping. What the governments of East Asia need to do is to reduce the regulatory barriers to trade and investment in their countries. Instead of expanding budgets for FTA activities and recruiting negotiation specialists, the governments should allocate more resources to implement economic reform.

\section{CONCLUSION}

We have examined the recent trends and characteristics of FTAs in East Asian countries. The proliferation of FTAs in the region is a sign of a departure from its commitment to the MFN principles of a multilateral trading system. In response, government organization has been restructured and more resources are allocated to FTA activities. The main conclusion of the study is that East Asia FTAs would produce fewer gains than the risks and problems associated with them. 
The following are the study's major findings. Firstly, the FTAs involving East Asian countries lead to only partial trade liberalization. The FTAs of developing countries based on the 'enabling clause' of GATT, such as the China-ASEAN agreement, provide liberalization for selected products. The FTAs of developed countries, such as the JapanSingapore agreement, are obliged to apply free trade in 'substantially all trade' by the GATT articles, but, in fact, exclude a wide range of exemption from liberalization. By protecting inefficient sectors, notably agriculture in Korea and Japan, FTAs work against gaining a comparative advantage. Second, FTA movements are not matched with trade flows. The bulk of actual trade flows occur between China, Korea, Japan and the U.S., but FTA agreements and discussions of East Asian countries are centered on ASEAN countries or countries without close trading ties, such as Chile and Mexico. This feature is distinctive from that of the EU and NAFTA, where FTAs are signed between close trading partners. Third, the benefits of East Asia FTAs are likely to be fairly limited. The volume of trade covered by the FTAs account for a minimal portion of total trade: for example, the Korea-Chile FTA covers 0.3 per cent of Korea's trade and the Japan-Mexico agreement covers 0.9 per cent of Japan's trade. The ongoing Korea-Japan FTA would have a bigger effect, but the progress of negotiation is slow and political obstacles lie ahead. Also the current studies predicting positive gains from FTAs depend greatly on assumptions and the model specification, and, therefore, need careful interpretation. Fourth, it is not likely that the East Asian FTAs will lead to a broader regional agreement or an East Asian Free Trade Area. Strong rivalry and competition, particularly between Japan and China, is an impediment. The discrepancies between the interested sectors also limit the chance of a free trade area embracing East Asia.

Since FTAs in East Asia are initiated for reasons ranging from a defensive motivation to regionalism in other parts of the world, policy prescription may not be simple. However, the study indicates that the East Asian countries need to refresh the merits of MFN based trade liberalization, and support new multilateral trade reforms in the WTO. The governments should make more efforts to expand economic reforms and reduce barriers to trade and investment rather than to allocate more resources and manpower to FTA activities.

\section{REFERENCES}

Asian Development Bank, 2002, "Preferential Trade Agreements in Asia and the Pacific," In Asian Development Outlook 2002, ADB.

Baldwin, Richard, 2004, "East Asian Regionalism: A Comparison with Europe," Unpublished paper presented at a seminar for 'FTA Policies of Korea and Japan and Policy Implications for a Bilateral FTA' May 28, Inha University, Incheon, Korea.

Bhagwati, Jagdish, David Greenaway and Arvind Panagaria, 1998, "Trading Preferentially: Theory and Policy,” The Economic Journal 108, 1128-1148. 
Brown, D.K., Deardorff, A.V. and Stern, R.M., 2003, "Multilateral, Regional and Bilateral Trade-Policy Options for the United States and Japan," The World Economy 26(6), 803-828.

Cheong, In-Kyo, 2001, "Korea-Japan FTA: Economic Effect and Policy Implications," KIEP Policy Analyses I, 01-04, Korea Institute for International Economic Policy, Seoul (in Korean).

Cheong, In-Kyo, 2002, East Asian Economic Integration: Recent Development of FTAs and Policy Implications, Korea Institute for International Economic Policy, Seoul.

Gordon, Bernard., 2003, “A High Risk Trade Policy,” Foreign Affairs 82(4), 105-118.

Hyun, Jung Taik, 2003, "Free Trade Agreement and Korea's Trade Policy," Journal of International and Area Studies 10(2), 21-37.

Hyun, Jung Taik and Jin Young, Hong, 2004, "The Trade Policy Decision Making Systems of Major Countries and Measures for Improving the Efficiency of Korea's Trade Policy," International Trade Law 59, 13-50 (in Korean).

International Monetary Fund, 2003, International Financial Statistics, IMF.

Igawa, Kazuhiro, 2004, “Japan's FTA Policy and Position for a Japan-Korea FTA,”, Unpublished paper presented at a seminar for "FTA Policies of Korea and Japan and Policy Implications for a Bilateral FTA' May 28, Inha University, Incheon, Korea.

Korea International Trade Association (KITA), 2003, Kita's DB, KITA http://db.kita.net

Korea Times, 2004, “Tough Realities of ROK-Japan Relations," 19 December 2004.

Krueger, Anne O., 1999, “Are Preferential Trading Arrangements Trade-Liberalizing or Protectionist?” Journal of Economic Perspectives 13(4), 105-124.

Lee, Chang-Jae, 2003, "Towards a Northeast Asian Economic Community: A Korean Perspective," in Yangseon Kim and Chang-Jae Lee eds., Northeast Asian Economic Integration: Prospects for a Northeast Asian FTA, Korea Institute for International Economic Policy, 264-284.

Low, Linda, 2004, "A Comparative Evaluation and Prognosis of Asia Pacific Bilateral and Regional Trade Agreements," Asia-Pacific Economic Literature 18(1), 1-11.

Ministry of Foreign Affairs and Trade of Korea website accessed 20 October 2004. http://www.mofat.go.kr 
Nam, Jong-Hyun, 2004, “A Critical Assessment of Korea's FTA Policy,” Working Paper, Institute of World Economy, Seoul (in Korean).

Park, Soon-Chan, 2004, "Prospects and Issues of Korea's FTA," Monthly World Economy 7(5), 53-61, Korea Institute for International Economic Policy, Seoul (in Korean).

Panagariya, Arvind, 1999, "The Regionalism Debate: An Overview," World Economy 22(4), 477-511.

Schott, Jeffrey J. and Goodrich Ben, 2004, "Reflection on Economic Integration in Northeast Asia," in Yoon Hyung Kim and Chang Jae Lee eds., Strengthening Economic Cooperation in Northeast Asia, Korea Institute for International Economic Policy, 33-64.

Seliger, Bernhard, 2003, “A Free Trade Area between Japan and Korea-Economic Prospects and Cultural Problems," Unpublished paper presented at the $4^{\text {th }}$ Inha-Le Havre International Conference on Regional Cooperation and Economic Integration, October 8-9, Inha University, Incheon, Korea.

Sheng, Lijun, 2003, "China-ASEAN Free Trade Area: Origins, Developments and Strategic Motivations," ISEAS Working Paper, Institute of Southeast Asian Studies, Singapore.

Snape, Richard H., 1996, “Trade Discrimination-Yesterday's Problem?" The Economic Record 72(219), 381-396.

Summers, Lawrence, 1991, "Regionalism and the World Trading System," Federal Reserve Bank of Kansas City, 295-301.

Urata, Shujiro, 2003, "Japan`s Strategy toward Free Trade Agreements," in Yangseon Kim and Chang-Jae Lee eds., Northeast Asian Economic Integration: Prospects for a Northeast Asian FTA, Korea Institute for International Economic Policy, Seoul, 97113.

Yomiuri On-line website accessed 26 February 2004. http://www.yomiuri.co.jp/index-e.htm 